\title{
Water Minimisation at Coal Fired Power Station Using Process Integration
}

\author{
D. Mokhonoana, G. Gericke and F. Waanders
}

\begin{abstract}
The primary objective of this study is to determine the possible reduction of the raw water intake of an existing power station by applying process integration techniques to optimise the use of water available within the system. The secondary objective is to reduce the waste water produced within the process, hence reducing the cost of water, reducing the amount of chemicals and reducing the energy needed to treat water. This will be achieved by considering the power plant system as a whole (i.e. integrated or holistic approach) in order to improve its design and/or operation which exploit the interactions between different units. This paper will describe the process that was followed to determine the suitability of process integration at The Power Station.
\end{abstract}

Keywords-Process integration, minimisation, objective function, optimisation.

\section{INTRODUCTION}

Water and energy are the basic needs for human existence, and due to population and industrial growth the need for both will continue to increase. As energy costs increase, the intersection between energy and water becomes important as the main primary resources for power generation are water and coal.

South Africa's power base is comprised mainly of coal fired generation. Eskom power stations supply about $95 \%$ of South Africa's electricity and more than half of the electricity used on the African continent [1]. The extensive use of coal to generate electricity is projected to continue for many years. Eskom uses approximately $2 \%$ of the country's total water consumption annually [2].

During the 2015/2016 financial year, Eskom used approximately 313 billion litres of water for electricity generation, mainly at its coal-fired power stations [2]. Water use targets, in terms of litres per unit of electricity sent out, are set for each power station every year. The objective is to bring Eskom's water consumption relative to power produced to 1.3 litres a kilowatt-hour by 2022 [3] Eskom recognised that the organisation would have to find ways of limiting increases in water consumption and

contribute to sustainable water use in South Africa. Eskom is thus committed and determined to support the drive to improve the management of South Africa's scarce water resources. Water Minimisation Approaches at the Power Station

D. Mokhonoana, School of Chemical and Minerals Engineering at the North-West University, Potchefstroom, South Africa

G. Gericke and F. Waanders, School of Chemical and Minerals Engineering at the North-West University, Potchefstroom, South Africa
The power station consists of six once through boilers and steam turbines each generating a maximum of $600 \mathrm{MW}$ of energy. Power Station receives raw water from the Vaal and Usutu water schemes for various uses. . The freshwater intake is about $110 \mathrm{ML} / \mathrm{d}$. Raw water is used in the plant processes such as cooling tower makeup, condenser makeup, and slurry preparation makeup, ash handling makeup, syngas humidification, quench system makeup, and demineralised water. The water balance model and diagram for a Power Station with specified process water volumes and quality standards for the various unit operations is included in table 1. A process flow diagram of water flow at the power station was developed (Fig 1).

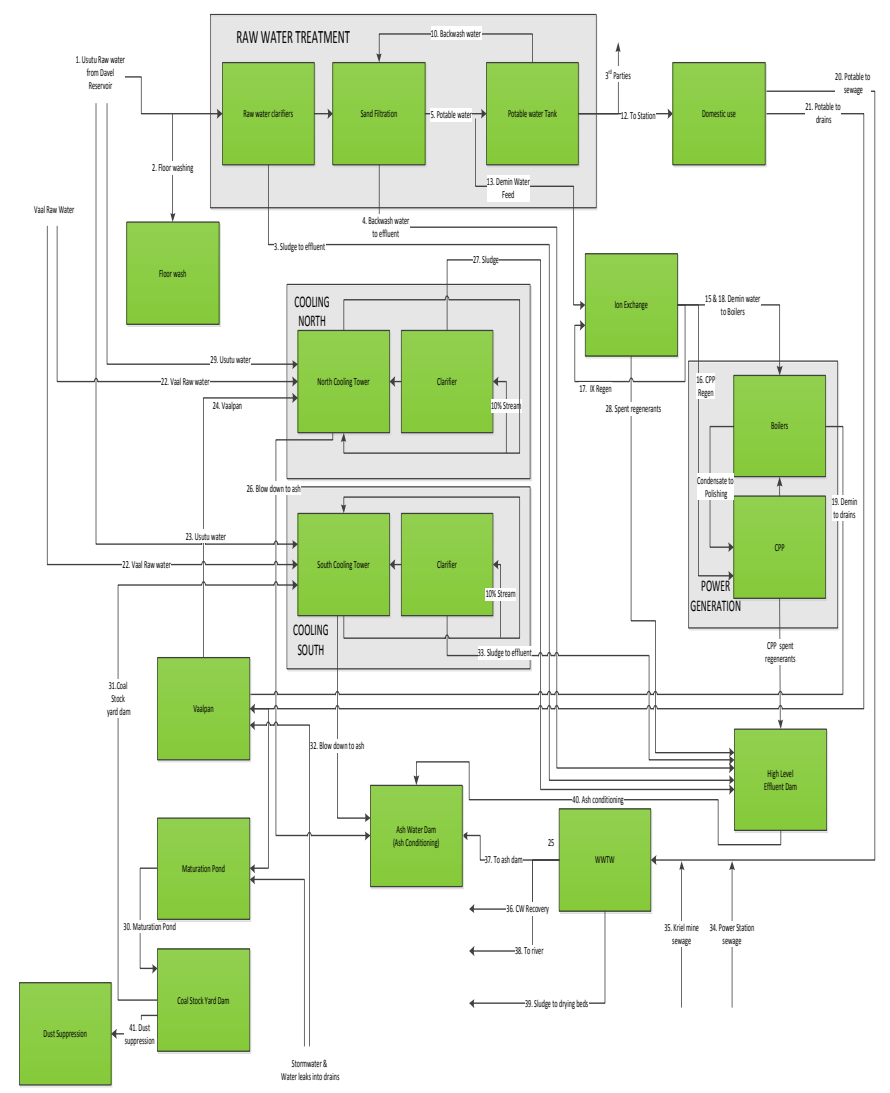

Fig 1: Block diagram of water network at the Power Station [4]

\section{INTRODUCTION OF PROCESS INTEGRATION PRINCIPLES}

Process Integration is a systematic technique used to identify, allocate, analyse and optimize a water network system for reducing freshwater consumption and minimize wastewater 
generation. Since its introduction by Wang and Smith (1994) [5], this technique has been one of the most widely used tools for conservation of water in industrial processes. There are three main water recovery schemes adopted in process integration [5] which are: re-use, recycle and regeneration.

Process integration techniques for water minimisation are initiated by identifying the water sources and water sinks of the network followed by matching appropriate sources and sinks as water quality allows. The water network therefore first has to be compiled and flow and quality data can subsequently be allocated to process units within the network.

For a single contaminant network a graphical approach can be used to obtain the optimum water network. For multiple contaminants, a mathematical programming approach is used as the graphical approach becomes tedious and inaccurate. The mathematical programming approach of water networks is based on the optimisation of a network superstructure. The superstructure of a water network is a description of all possible feasible connections between water using processes and water treating processes. The optimal solution is a subset of the superstructure and is identified by the use of optimisation methods. Based on this superstructure, a mathematical model, describing the problem with all economic, geographical, control and safety constraints included, is built. This enables the technique to deal with more detailed design considerations such as data uncertainties, life-cycle impacts, network topology and capital costs [6]. The optimisation problem represented as a mathematical model is then solved using rigorous algorithms to obtain global or near-global solutions. Minimum water targets are determined simultaneously with the network design. GAMS software is used to develop the process integration model. GAMS is specifically designed for modelling linear, nonlinear and mixed integer optimisation problems [7]. The system's inherent solvers allow a user to solve complex problems with a simple and very flexible setup.

\section{APPLYING THE PROCESS INTEGRATION PRINCIPLES to THE POWER STATION}

The flow rate, total dissolved solids concentration and the conductivity of the various streams of the The power station were captured and used as a guide for the process flow.

\section{OBJECTIVE FUNCTION}

The objective function is the functional property to be optimised (minimised or maximized). The objective function focusing on the minimization of the total freshwater intake into the facility is given in constraint (1a). It may also include the amount of wastewater generated as in (1b) or minimize the costs associated with intake of freshwater and treatment of wastewater as in (1c)

$$
\begin{aligned}
& \text { Min } F W=\sum_{i \in I} F W_{i} \\
& \text { Min } F W, W W=\sum_{i \in I} F W_{i}+\sum_{j \in J} W W_{j}
\end{aligned}
$$

$$
\begin{aligned}
& \text { Min Cost }=\sum_{i \in I} F W_{i} \times \operatorname{Cost} F W+ \\
& \sum_{j \in J} W W_{j} \times \text { TreatmentCost } W W
\end{aligned}
$$

All three objective functions were used to minimize the respective variables. This eventually will enable power station management to make decisions from both a water use target and cost point of view.

\section{RESULTS AND DISCUSSION}

Flow data used in the model was taken from the Saltman model (Saltman is a software used by Eskom power station for salt and water balance within the water process) provided by The Power Station. The freshwater intake of $109730 \mathrm{~m}^{3} /$ day predicted by the Saltman model compares well to the current 110 to $115 \mathrm{Ml} / \mathrm{d}$ water usage reported by the power station. A separate model was compiled, which optimizes the water utilisation network without the regenerator being used.

Three different objective functions were set (given by equations $1 \mathrm{a}-\mathrm{c}$ ) to minimize freshwater intake, freshwater and wastewater combined or costs associated with water intake and treatment respectively. Each of these targets provided unique networks and different targets to work towards by the power station management, whether it is in order to reach the minimum freshwater intake, to minimize waste production or endeavouring to minimize costs associated with water usage and waste management.

After formulating the initial model with sources and sinks as listed in Table 2, it was apparent that certain modelling outcomes could contribute to more effective water management, but may not necessarily be implemented without further investment or certain commitments by power station management.

The outcomes from this study can be summarised as follows:

(i) Re-use of wastewater treatment plant effluent can be used as make up to cooling tower.

(ii) With the two cooling towers operating at different cycles of concentration $(\mathrm{CoC})$, the blow down water of the South Cooling Tower (operated at lower $\mathrm{CoC}$ ) is of an acceptable quality to feed into the North Cooling ITower

(iii) Water from other sources e.g. regenerates can be used for floor washing operations

\section{CONCLUSIONS \& ReCOMMENDATIONS}

The following conclusions can be made from the findings in this document:

- Savings of between $4 \%$ and $13 \%$ may be possible by changing the way water is currently utilised and re-used at the station. These figures translate to 1/uso values of 2.23 to 2.04 respectively. These savings still do not achieve the design water consumption target of $1.8 \mathrm{l} /$ uso. The same objective function values are achieved by minimizing freshwater consumption or the sum of freshwater consumption and wastewater produced.

- Reuse of the wastewater treatment plant effluent has a direct impact on water consumption and investment in 
infrastructure to enable the introduction of good quality sewage effluent into the cooling towers shows savings in the order of R 2.2 million per year.

- Optimisation of the stations water network still brings 3\% savings without implementation of any of the three preliminary findings mentioned.

- Observations on site showed a significant amount of water that end up in the station drains. With the bulk of water use at the station going to the cooling towers it is expected that regardless if any other of the findings of this study is implemented, effective maintenance on cooling cycle equipment (such as valves, ejector weirs etc.) may reduce water consumption by as much as $5 \%$ or R 1 million/month. Findings in this report are based on input water demands (for respective unit process) that include prevailing leaks at the station. Any savings through maintenance is additional to the results already shown in this report.

- Management of the cooling cycle and especially blow down water with related procedures have a significant impact on the amount of freshwater intake. A thorough understanding of the intricacies of cooling tower operation and performance is critical to optimise this. The appointment of a task team to perform this work approximates savings of R1.5 Million per month after initial investment of an estimated R360 000 and it is highly recommended design water consumption target of $1.8 \mathrm{l}$ /uso. The same objective function values are achieved by minimizing freshwater consumption or the sum of freshwater consumption and wastewater produced.

- Reuse of the wastewater treatment plant effluent has a direct impact on water consumption and investment in infrastructure to enable the introduction of good quality sewage effluent into the cooling towers shows savings in the order of R 2.2 million per year.

- Optimisation of the stations water network still brings 3\% savings without implementation of any of the three preliminary findings mentioned.

- Observations on site showed a significant amount of water that end up in the station drains. With the bulk of water use at the station going to the cooling towers it is expected that regardless if any other of the findings of this study is implemented, effective maintenance on cooling cycle equipment (such as valves, ejector weirs etc.) may reduce water consumption by as much as $5 \%$ or R1 million/month. Findings in this report are based on input water demands (for respective unit process) that include prevailing leaks at the station. Any savings through maintenance is additional to the results already shown in this report.

-Management of the cooling cycle and especially blow down water with related procedures have a significant impact on the amount of freshwater intake. A thorough understanding of the intricacies of cooling tower operation and performance is critical to optimise this. The appointment of a task team to perform this work approximates savings of R1.5 Million per month after initial investment of an estimated R360 000 and it is highly recommended.

\section{APPENDIX}

Sets

$$
\begin{aligned}
& I=\{i \mid i=\text { water using operation }(\text { sink })\} \\
& J=\{j \mid j=\text { water generating operation (source) }\}
\end{aligned}
$$

\section{Continuous variables}

$$
\begin{aligned}
& F W_{i}=\text { freshwater into sink } i \\
& W W_{j}=\text { wastewater stream from source } j
\end{aligned}
$$

\section{ACKNOWLEDGMENT}

I thank my creator God who guided and sustained me to accomplish this study. My sincere gratitude and acknowledgement goes to my supervisor Professor F.Waanders and my co-supervisor Gerhard Gericke for valuable guidance, constructive criticism, continuous support of my Msc study, for their patience, motivation, and immense knowledge and inspiring encouragement. Their guidance helped me in all the time of research and writing of this paper and dissertation. I could not have imagined having a better supervisor and co-supervisor for my Msc study. Many thanks go to Eskom my employer who have invested the company's resources in achieving the goal.

\section{REFERENCES}

[1] https://www.dwa.gov.za/io/Docs/CMA/CMA\%20GB\%20Training\%20 Manuals/gbtrainingmanu alchapter1.pdf

[2] http://nepadwatercoe.org/wp-content/uploads/Strategic-Overview-of-the -Water-Sector-in-South-Africa-2013.pdf

[3] http://www.iol.co.za/business/companies/eskom-to-cut-water-use-by-26 0bn-litres-1.1326359\#.U6rGOE1DGss [y] June 252012 at 05:00am

[4] The Operating Manual 114463/12096/11957

[5] Wang, Y. P. \& Smith, R., 1994a. Wastewater Minimisation. Chemical Engineering Science, 49(7), pp. 981-1006. https://doi.org/10.1016/0009-2509(94)80006-5

[6] Tan, R. R., Ng, D. K. S., Foo, D. C. Y. \& Aviso, K. B., 2009. A superstructure model for the synthesis of single-contaminant water networks with partitioning regenerators. Process Safety and Environmental Protection, Volume 87, pp. 197-205 https://doi.org/10.1016/j.psep.2009.01.001

[7] www.gams.com, March 2014 


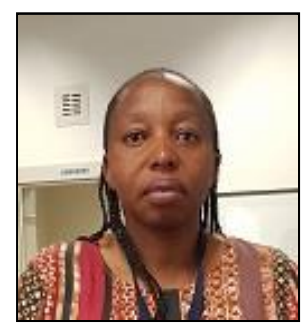

Dorian Mokhonoana obtained her diploma in Chemical Engineering at Witwatersrand Technikon (University of Johannesburg), she then pursued her studies and obtained a B-Tech Degree from Pretoria Technikon (Tshwane University of . After that she studied with the University of Pretoria were she obtained her Bsc Honors in Applied Science. She worked for the Department of Labour in Johannesburg as an Occupational Health and Safety Inspector from 1996 to 2000. From 2001 she joined Eskom in Generation at Lethabo power station as a Systems Engineer, working at boiler plant department until 2006, from there she moved to Eskom Research as an Engineer and worked on water projects. She is involved in various projects which involve water minimization, optimization of antiscalant, clean in place and membranes.

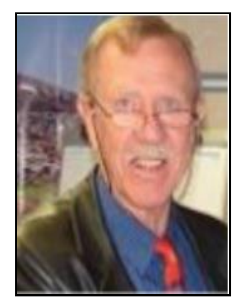

Prof. Waanders obtained his Bsc Degree in Physics and Geology, M.sc and Dsc degree in Nuclear Physics at the PU for CHE. From 1976 until 1979 he was a geologist at the Buffelsfontein Gold Mine before returning to the University. From1979 until 1989 he lectured in the department of Physics at the PU for CHE, but during 1986 - 1987 and 1998 he was a guest lecturer/researcher at the Munster University, Germany. In 1990 he joined the Geology Department at the PU for CHE. In 1992 he was asked to join the Metallurgical Engineering Department and completed his engineering studies to be able to register as professional engineer and in 1997 the Metallurgical Engineering Department was incorporated in the school of Chemical and Mineral Engineering where he is currently a professor and the director of the school. $\mathrm{He}$ has delivered numerous papers on various topics at national and international conferences and is the author/co-author of more than 150 publications of international standards and he was part of the 3-man team that inscribed the Vredefort Dome as World Heritage Site in 2005.

Prof. Waanders is a member of the South Africa Institute of Physics, South Africa Institute of Mining and Metallurgy and a fellow member of the Geology Society of South Africa. He is a registered engineer and natural scientist. He is married to Petro, private practicing dietician.

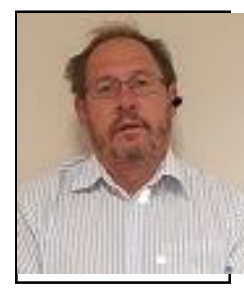

Gerhard Gericke obtained his Diploma in Analytical Chemistry from Witwatersrand Technikon in 1984, he then continued with his studies at the University of the Western Cape were he completed Msc in 2002. He started working at Eskom from 1982, he hasworked in various projects, and he has a specialist in the following chemistry disciples Water and Applied Chemistry, Environmental Chemistry, Fuel cell technology, Water treatment technologies and jueous Natural Organic mtmatter. He has presented, provided training and itten various publications in in conferences and workshops. 